Published in final edited form as:

Org Lett. 2006 May 11; 8(10): 2123-2126.

\title{
Synthesis of ent-Thallusin
}

\author{
Xiaolei Gao ${ }^{\dagger}$, Yoshihide Matsuo ${ }^{\ddagger}$, and Barry B. Snider ${ }^{\dagger}$ \\ $\dagger$ Department of Chemistry MS 015, Brandeis University, Waltham, Massachusetts 02454-9110 \\ \$Marine Biotechnology Institute Co. Ltd., 3-75-1 Heita, Hamaishi-shi, Iwate 026-0001, Japan
}

\begin{abstract}
A three-step route from sclareol oxide (6) to bromo ester 4 in 53\% overall yield was achieved using the efficient oxidation of an allylic bromide to an enal with bis(2,4,6-trimethylpyridine)silver(I) hexafluorophosphate in DMSO. Stille coupling of bromo ester 4 with stannylpyridine 5 gave the trimethyl ester of ent-thallusin in 54-92\% yield by the stoichiometric conversion of 4 to a vinyl palladium intermediate prior to the addition of 5 to the reaction.
\end{abstract}

Matsuo and co-workers recently reported the isolation of thallusin (1) from the epiphytic marine bacterium strain YM2-23 belonging to the Cytophaga-Flavobacter-ium-Bacteroides group that was isolated from a green alga Monostroma sp. ${ }^{1}$ Pure thallusin strongly induced the differentiation of Monostroma oxyspermum with a minimum effective concentration between $1 \mathrm{fg} / \mathrm{mL}$ and $1 \mathrm{ag} / \mathrm{mL}$. The structure of 1 was established by X-ray crystal structure determination of a derivative Me1H1W4 (16); the absolute stereochemistry was not assigned.

Thallusin (1) contains a terpenoid lower half attached to a 2,6-pyridinedicarboxylic acid. We thought that it should be possible to prepare 1 by either a Heck reaction of bromopyridine $3^{2}$ with unsaturated ester $\mathbf{2}$ or by a Stille coupling of bromo ester $\mathbf{4}$ with stannylpyridine $\mathbf{5}$, which should be readily available from $\mathbf{3}$ (see Scheme 1). Esters $\mathbf{2}$ and $\mathbf{4}$ should be readily available from sclareol oxide $\mathbf{6}$, which can be prepared by oxidation of sclareol with $\mathrm{KMnO}_{4}$ and $\mathrm{MgSO}_{4}$ in acetone to give a hydroxy ketone, ${ }^{3}$ followed by cyclization to the dihydropyran by heating in benzene at reflux. ${ }^{4}$

Treatment of sclareol oxide (6) ${ }^{3,4}$ with 2 equiv of NBS and 2.2 equiv of $\mathrm{CaCO}_{3}$ in $\mathrm{CCl}_{4}$ or $\mathrm{CH}_{2} \mathrm{Cl}_{2}$ at $25^{\circ} \mathrm{C}$ for $1 \mathrm{~h}$ afforded dibromide $7 \mathrm{in} 61 \%$ yield as previously described (see Scheme 2). ${ }^{5}$ Reaction of 7 with $\mathrm{CsOAc}$ ( 3 equiv) in DMF at $70{ }^{\circ} \mathrm{C}$ for $4 \mathrm{~h}$ provided allylic acetate 8 in $96 \%$ yield. Saponification of $\mathbf{8}$ with $\mathrm{K}_{2} \mathrm{CO}_{3}$ in $\mathrm{MeOH}$ afforded allylic alcohol 9 as a colorless oil that rapidly decomposed to a thick dark green oil. To our surprise, the NMR spectrum of this oil indicated the presence of almost pure desbromo aldehyde 10, which was obtained in $92 \%$ yield from $\mathbf{8}$. Presumably, protonation of the double bond of $\mathbf{9}$ followed by loss of a proton from the $\mathrm{CH}_{2} \mathrm{OH}$ group affords a bromo enol, which loses $\mathrm{HBr}$ to give $\mathbf{1 0}$. Oxidation of $\mathbf{1 0}$ with $\mathrm{NaClO}_{2}, \mathrm{NaH}_{2} \mathrm{PO}_{4}$, and 2-methyl-2-butene afforded the carboxylic acid which was treated with $\mathrm{CH}_{2} \mathrm{~N}_{2}$ to give methyl ester 2 in $80 \%$ yield.

Unfortunately, attempted Heck coupling of bromopyridine $\mathbf{3}^{2}$ with ester $\mathbf{2}$ under a variety of conditions gave mainly recovered starting materials. However, reaction of $\mathbf{3}$, methyl acrylate, $\mathrm{Et}_{3} \mathrm{~N}$, tri-o-tolylphosphine, and $\mathrm{Pd}(\mathrm{OAc})_{2}$ in $\mathrm{CH}_{3} \mathrm{CN}$ at $90{ }^{\circ} \mathrm{C}$ for $10 \mathrm{~h}$ gave the Heck product methyl 3-(2,6-dicarbomethoxy-3-pyridinyl)-2-propenoate in 95\% yield. This indicates that the problem in the desired Heck reaction involves ester $\mathbf{2}$, which may be too hindered to react with 
the pyridylpalladium intermediate derived from 3 . Alternately, it is possible that addition of the pyridylpalladium intermediate to $\mathbf{2}$ occurs with the desired regioselectivity, but that $\beta$ hydride elimination cannot occur because the hydrogen is not syn to the palladium. We therefore halogenated $\mathbf{2}$ to prepare a precursor for a Stille coupling.

Bromination of 2 with $\mathrm{Br}_{2}$ and $\mathrm{CaCO}_{3}$ in $\mathrm{MeOH}$ at $0{ }^{\circ} \mathrm{C}$ for 30 min afforded bromo ester 4 , which was hard to purify, in variable yield (30-50\%). Reaction of $\mathbf{2}$ with $\mathrm{ICl}$ under similar conditions gave the unstable iodo methoxy ester 11 in $90 \%$ yield. ${ }^{6}$ Reaction of $\mathbf{2}$ with $\mathrm{I}_{2}$ and ceric ammonium nitrate in $\mathrm{CH}_{3} \mathrm{CN}^{7}$ provided the rearranged tetrahydrofuran $\alpha$-keto ester 12 in $95 \%$ yield. Presumably the first step involves the formation of an iodo nitrate analogous to 11. Hydrolysis followed by intramolecular $S_{N} 2$ reaction of the $\varepsilon$-hydroxy- $\beta$-iodo- $\alpha$-keto ester affords 12. The stereochemistry of $\mathbf{1 2}$ was established by an NOE between $\mathrm{H}_{2}$ and the $\mathrm{C}_{3 \mathrm{a}^{-}}$ methyl group.

The five-step sequence that converts dibromide $\mathbf{7}$ to bromo ester $\mathbf{4}$ was unsatisfying because of its length and the difficulty of obtaining pure 4. Moreover, the necessity for introducing the vinylic bromide twice was aesthetically unappealing. We therefore set out to convert dibromide 7 to bromo ester 4 without proceeding through the unstable allylic alcohol 9.

The silver-assisted oxidation of allylic bromides to aldehydes in DMSO using silver salts with non-nucleophilic counterions is well known. ${ }^{8}$ An oxysulfonium salt forms slowly over 1-18 $\mathrm{h}$ and is converted to the aldehyde by addition of $\mathrm{Et}_{3} \mathrm{~N}$. Unfortunately, $\mathrm{AgBF}_{4}$ and other silver salts with non-nucleophilic counterions are hygroscopic and hard to handle. Bis(2,4,6trimethylpyridine)silver(I) hexafluoro-phosphate, ${ }^{9}$ which is easily prepared and isolated by precipitation from water, is not hygroscopic and can be easily stored and handled. We were delighted to find that reaction of dibromide 7 with 1.5 equiv of bis(2,4,6-trimethylpyridine) silver(I) hexafluorophosphate in DMSO at $25^{\circ} \mathrm{C}$ for $5 \mathrm{~h}$ without added base afforded $\beta$-bromo enal 13 in 87\% yield (see Scheme 3). The 2,4,6-trimethylpyridine liberated in the formation of $\mathrm{AgBr}$ converts the oxysulfonium salt to the aldehyde and $\mathrm{Me}_{2} \mathrm{~S}$.

Corey-Gilman-Ganem oxidation ${ }^{10}$ of enal 13 with $\mathrm{MnO}_{2}, \mathrm{NaCN}$, and $\mathrm{HOAc}$ in $\mathrm{MeOH}$ afforded the desired bromo ester $\mathbf{4}$ in $99 \%$ yield. Using this sequence bromo ester 4 is available in $53 \%$ overall yield from sclareol oxide (6) in only three steps.

Coupling ${ }^{11}$ of bromopyridine $3^{2}$ and excess hexabutyl-ditin catalyzed by $2 \mathrm{~mol} \%$ $\left(\mathrm{Ph}_{3} \mathrm{P}\right)_{2} \mathrm{PdCl}_{2}$ in toluene at reflux for $3 \mathrm{~h}$ afforded the requisite stannylpyridine $\mathbf{5}$ in an unoptimized $41 \%$ yield. With both bromo ester $\mathbf{4}$ and stannylpyridine $\mathbf{5}$ in hand, we turned to the crucial Stille coupling.

Initial attempts at Stille coupling of $\mathbf{4}$ and $\mathbf{5}$ were not promising. For instance, reaction of $\mathbf{4}, 2$ equiv of 5,10 mol \% $\left(\mathrm{Ph}_{3} \mathrm{P}\right)_{4} \mathrm{Pd}$, and 1.1 equiv of $\mathrm{CuI}$ in $\mathrm{DMF}$ at $50{ }^{\circ} \mathrm{C}$ for $12 \mathrm{~h}$ provided only $10 \%$ of the desired Stille coupling product 14 . The major products were recovered $4(86 \%)$ and tetramethyl 3,3'-bipyridine-2,2',6,6'-tetracarboxylate formed by homocoupling of stannylpyridine 5. The Pd-catalyzed formation of biaryls from stannylbenzenes has been described. ${ }^{12}$ The formation of the bipyridine suggests that adventitious Pd(II) transmetallates with the aryl tin bond of $\mathbf{5}$ more readily than $\operatorname{Pd}(0)$ inserts in the vinyl bromide bond of $\mathbf{4}$. It should be possible to prevent this by reaction of bromo ester $\mathbf{4}$ with a stoichiometric amount of $\operatorname{Pd}(0)$ to form the vinylpalladium intermediate before the addition of stannylpyridine $\mathbf{5}$.

We were delighted to find that reaction of bromo ester 4 with $\left(\mathrm{Ph}_{3} \mathrm{P}\right)_{4} \mathrm{Pd}$ (1 equiv) in wet DMF in a microwave oven at $90{ }^{\circ} \mathrm{C}$ for $15 \mathrm{~min}$, followed by addition of $\mathrm{CuI}$ (1.5 equiv) and stannylpyridine 5 ( 1.5 equiv) and heating in a microwave oven at $90{ }^{\circ} \mathrm{C}$ for an additional 30 min provided thallusin trimethyl ester $(\mathrm{Me} 1, \mathbf{1 4})$ in $92 \%$ yield (see Scheme 4). Yields were reproducibly above $90 \%$ using $5 \mathrm{mg}$ of $\mathbf{4}$ in a total of $2 \mathrm{~mL}$ of DMF. The use of $\mathrm{CuI}$ is 
critical $^{13}$ as is the presence of water $(0.1 \%)$. Unfortunately, increasing the scale to $25 \mathrm{mg}$ reduced the yield to $<20 \%$ probably because of problems with effective stirring of a larger volume heterogeneous reaction in the microwave tube. A scale-independent thermal procedure was therefore developed. Reaction of bromo ester 4 with $\left(\mathrm{Ph}_{3} \mathrm{P}\right)_{4} \mathrm{Pd}$ (1 equiv) in wet DMF at $60{ }^{\circ} \mathrm{C}$ for $6 \mathrm{~h}$, followed by addition of $\mathrm{CuI}$ (1.5 equiv) and stannylpyridine 5 (1.5 equiv) and heating at $60{ }^{\circ} \mathrm{C}$ for an additional $12 \mathrm{~h}$ provided $14(45 \mathrm{mg}, 54 \%) .{ }^{14}$ The $500 \mathrm{MHz}{ }^{1} \mathrm{H}$ NMR spectra of $\mathbf{1 4}$ in both DMSO- $d_{6}$ and $\mathrm{CDCl}_{3}$ are identical to those of the natural product.

The ${ }^{13} \mathrm{C}$ NMR spectral data differ by $0.2-1.6 \mathrm{ppm}$ from those reported, but the natural product data were determined by analysis of HSQC and HMBC data.

Saponification of 14 with excess $\mathrm{NaOD}$ in $\mathrm{D}_{2} \mathrm{O}$ at $100^{\circ} \mathrm{C}$ for 30 min followed by concentration afforded the trisodium salt of thallusin (1). The NMR spectral data, which are sensitive to both $\mathrm{pH}$ and concentration, correspond well to those previously reported. ${ }^{1}$

Derivatives 15 and 16 were prepared as described by Matsuo and co-workers to assign the absolute stereochemistry of thallusin. Reduction of $\mathbf{1 4}$ with $\mathrm{NaBH}_{4}$ in $4: 1 \mathrm{Et}_{2} \mathrm{O} / \mathrm{MeOH}$ at 25 ${ }^{\circ} \mathrm{C}$ for $1 \mathrm{~h}$ provided triol $\mathbf{1 5}$ in $91 \%$ yield. Treatment of $\mathbf{1 5}$ with $6 \mathrm{M} \mathrm{HCl}$ in $\mathrm{MeOH}$ afforded 16 in 53\% yield after recrystallization from ether. The optical rotations of synthetic 15 $\left([\mathrm{g}=\mathrm{a}]_{\mathrm{D}}+77\right)$ and $\mathbf{1 6}\left([\mathrm{g}=\mathrm{a}]_{\mathrm{D}}+36\right)$ correspond closely in magnitude but are of opposite sign to those of natural $\mathbf{1 5}\left([\mathrm{g}=\mathrm{a}]_{\mathrm{D}}-73.5\right)$ and $\mathbf{1 6}\left([\mathrm{g}=\mathrm{a}]_{\mathrm{D}}-41\right)$. The absolute configuration of sclareol and sclareol oxide has been established as that shown. ${ }^{15}$ Therefore structure $\mathbf{1}$ is ent-thallusin and the natural product has the opposite absolute stereochemistry to that shown.

Unfortunately, diterpenes that can be converted to sclareol oxide in the opposite enantiomeric series are not readily available in high enantiomeric excess. ent- Sclareol has been isolated once from Conyza trihecatactis. ${ }^{16}$ The related diterpene copalic acid ${ }^{17}$ with the same absolute stereochemistry as thallusin can be isolated from copaiba oil in up to $46 \%$ enantiomeric excess. 18 The widely used natural sweetener stevioside contains a tetracyclic diterpene with the same absolute stereochemistry as thallusin. ${ }^{19}$

As reported by Matsuo, ${ }^{1}$ triester 14 and ent-thallusin (1) have broad ${ }^{1} \mathrm{H}$ and ${ }^{13} \mathrm{C}$ NMR spectra at $25^{\circ} \mathrm{C}$ due to slow rotation about the vinyl pyridine bond. The NMR spectra of 14 in $\mathrm{CDCl}_{3}$ at $55{ }^{\circ} \mathrm{C}$ are much sharper indicating that rotation is fast on the NMR time scale at this temperature. Triol 15 has a broadened ${ }^{1} \mathrm{H}$ NMR spectrum at $25^{\circ} \mathrm{C}$ and shows two discrete rotamers in the ${ }^{13} \mathrm{C}$ NMR spectrum as previously reported. ${ }^{1}$ The ${ }^{1} \mathrm{H}$ and ${ }^{13} \mathrm{C}$ NMR spectra of diol $\mathbf{1 6}$ are sharp because the formation of the additional ring removes conformational freedom.

ent-Thallusin (1) shows no morphogenesis inducing activity or growth inhibitory activity against $M$. oxyspermum in the $100 \mathrm{ng} / \mathrm{mL}$ to $1 \mathrm{pg} / \mathrm{mL}$ range after 10 days cultivation, while natural thallusin is active at these concentrations. A mixture of natural thallusin and entthallusin shows the same activity as thallusin by itself. These results indicate that ent-thallusin does not have significant biological activity.

In conclusion, we have developed a three-step route from sclareol oxide to bromo ester 4 in $53 \%$ overall yield using the efficient oxidation of allylic bromide to enal 13 with bis $(2,4,6$ trimethylpyridine)silver(I) hexafluorophos-phate in DMSO. This reagent is much easier to use than hygroscopic silver salts such as $\mathrm{AgBF}_{4}$. Stille coupling of bromo ester 4 with stannylpyridine 5 gave the trimethyl ester of ent-thallusin in 54-92\% yield by the stoichiometric conversion of $\mathbf{4}$ to a vinyl palladium intermediate prior to the addition of $\mathbf{5}$ to the reaction.

\section{Supplementary Material}

Refer to Web version on PubMed Central for supplementary material. 


\section{Acknowledgment}

We thank the NIH (GM50151) for generous financial support. We thank Prof. Jin-Quan Yu, Brandeis University for helpful discussions on the palladium coupling.

\section{References}

1. Matsuo Y, Imagawa H, Nishizawa M, Shizuri Y. Science 2005;307:1598. [PubMed: 15761147]

2. Zimmermann N, Meggers E, Schultz PG. Bioorg. Chem 2004;32:13-25. [PubMed: 14700559]

3. Leite MAF, Sarragiotto MH, Imamura PM, Marsaioli AJ. J. Org. Chem 1986;51:5409-5410.

4. Barrero AF, Alvarez-Manzaneda EJ, Altarejos J, Salido S, Ramos JM. Tetrahedron 1993;49:1040510412.

5. Aricu AN, Yu Andreeva, I. Vlad PF. Russ. Chem. Bull 1996;45:2645-2648.Izvest. Akad. Nauk, Ser. Khim 1996:2785-2789.Chem. Abstr 1997;126:157649m.

6. The spectral data are analogous to those of related compounds:Faivre V, Lila C, Saroli A, Doutheau A. Tetrahedron 1989;45:7765-7782.

7. Zhang FJ, Li YL. Synthesis 1993:565-567.

8. Ganem B, Boeckman RK Jr. Tetrahedron Lett 1974:917-920.

9. Homsi F, Robin S, Rousseau G. Org. Synth 1999;77:206-211.

10. Corey EJ, Gilman NW, Ganem BE. J. Am. Chem. Soc 1968;90:5616-5617.

11. Benaglia M, Toyota S, Woods CR, Siegel JS. Tetrahedron Lett 1997;38:4737-4740.

12. Parrish JP, Flanders VL, Floyd RJ, Jung KW. Tetrahedron Lett 2001;42:7729-7731.

13. Farina V, Kapadia S, Krishnan B, Wang C, Liebeskind LS. J. Org. Chem 1994;59:5905-5911.

14. Thermal Stille coupling of $\mathbf{4}$ and $\mathbf{5}$ at $90{ }^{\circ} \mathrm{C}$ gave $\mathbf{1 4}$ in about $30 \%$ yield at short reaction times (20 $\mathrm{min}, 30 \mathrm{~min})$ and 50-60\% yield with longer reaction times $(2 \mathrm{~h}, 2.5 \mathrm{~h})$.

15. Klyne, W.; Buckingham, J. Atlas of Stereochemistry-Absolute Configurations of Organic Molecules. Oxford University Press; New York: 1978. p. 108-111.

16. Torrenegra R, Robles J, Waibel R, Löwel M, Achenbach H. Phytochemistry 1994;35:195-199.

17. Nakano T, Djerassi C. J. Org. Chem 1961;26:167-173.

18. Nunes FMN, Imamura PM. J. Braz. Chem. Soc 1996;7:181-186.

19. Geuns JMC. Phytochemistry 2003;64:913-921. [PubMed: 14561506] 


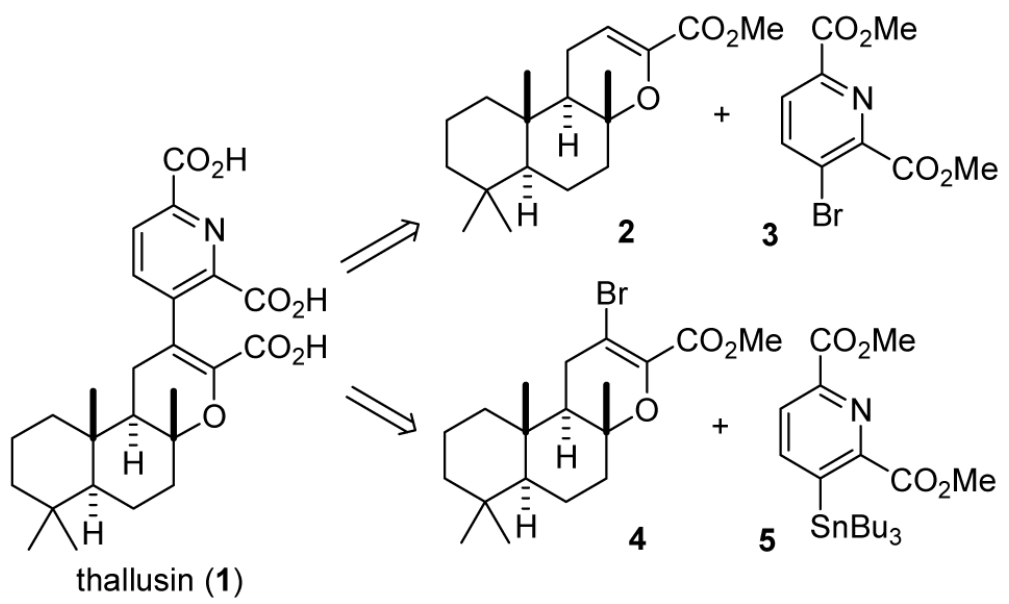

Scheme 1.

Retrosynthesis of Thallusin (1) 

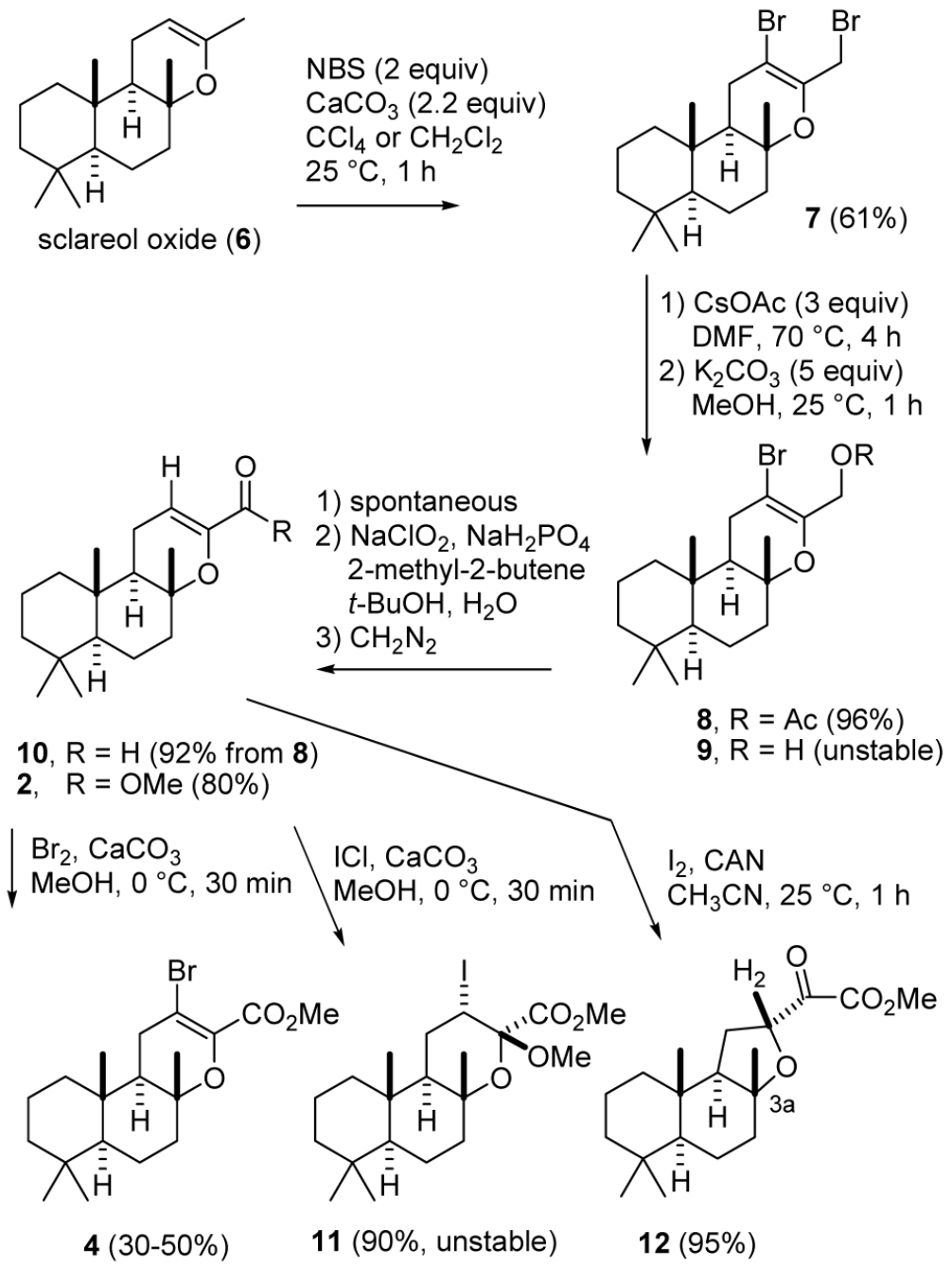

Scheme 2.

Preparation of $\mathbf{2}$ and $\mathbf{4}$ 
<smiles>CC1(C)CCCC2(C)[C@H]1CC[C@@]1(C)OC=C(Br)C[C@H]21</smiles>

7<smiles>COC(=O)c1ccc(Br)c(C(C)=O)n1</smiles>

3<smiles>[R]C(=O)C1=C(Br)CC2[C@](C)(CC[C@]3(C)C(C)(C)CCC[C@@]23C)O1</smiles>

13, $\mathrm{R}=\mathrm{H}(87 \%)$

4, $\mathrm{R}=$ OMe $(99 \%)$

$\left(\mathrm{Ph}_{3} \mathrm{P}\right)_{2} \mathrm{PdCl}_{2}$ (0.02 equiv) $\left(\mathrm{Bu}_{3} \mathrm{Sn}\right)_{2}$ (3 equiv) toluene, reflux, $3 \mathrm{~h}$<smiles>CCCCc1ccc(C(C)=O)nc1C(OC)OC</smiles>

$5(41 \%)$

Scheme 3.

Preparation of $\mathbf{4}$ and $\mathbf{5}$ 

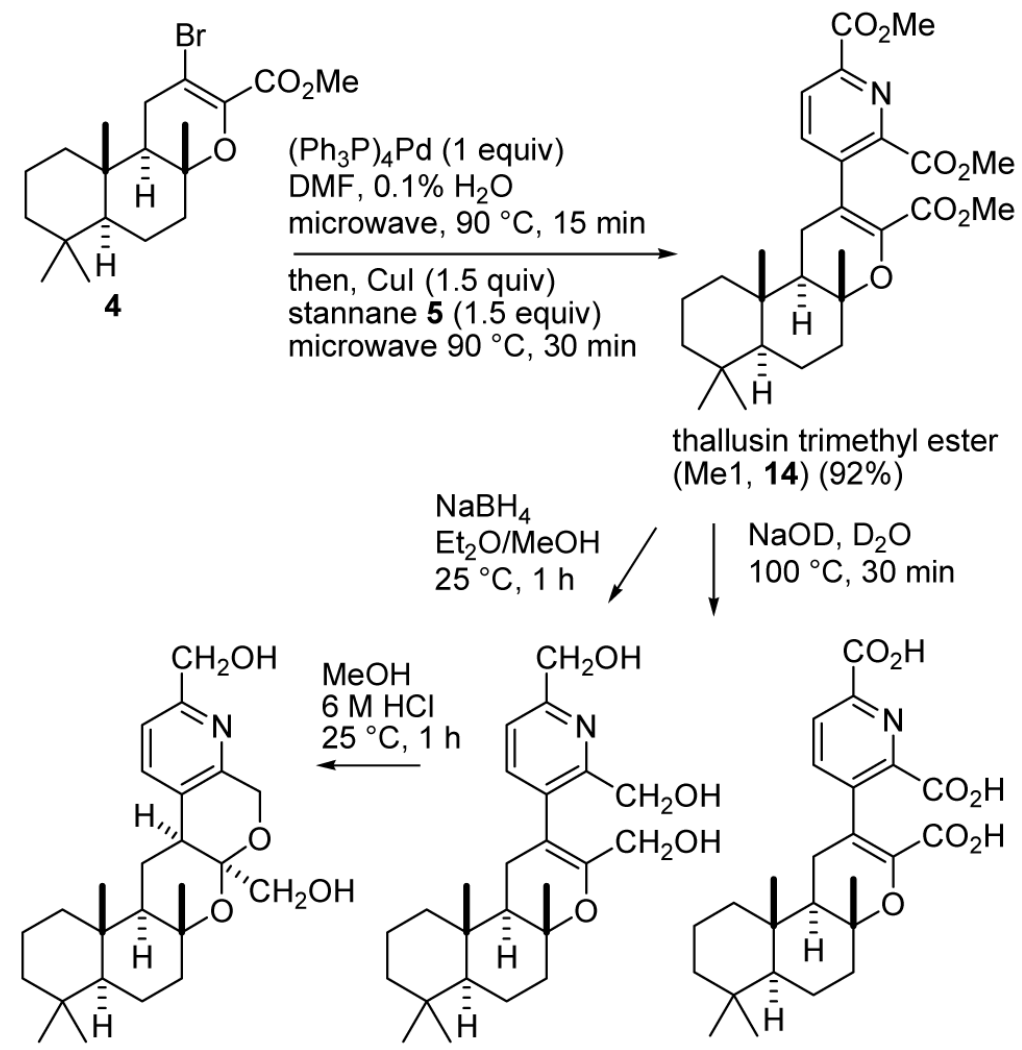

Scheme 4.

Synthesis of ent-thallusin (1) 